Article

\title{
Competing Tenures: Implications for REDD+ in the Democratic Republic of Congo
}

\author{
Raymond Achu Samndong * and Arild Vatn
}

Department of International Environment and Development Studies, Faculty of Landscape and Society, Norwegian University of Life Sciences (NMBU), 1430 Ås, Norway; arild.vatn@nmbu.no

* Correspondence: rsamndong@thetenurefacility.org

Received: 19 September 2018; Accepted: 18 October 2018; Published: 24 October 2018

\begin{abstract}
The capacity of the Democratic Republic of Congo (DRC) forests to sequestrate carbon has attracted interest from the international community to protect forests for carbon storage and alleviate rural poverty by establishing REDD+ (Reduced Emissions from Deforestation and Forest Degradation). Using information gathered from interviews, focus groups, field observations, and policy document analysis, this paper demonstrates that REDD+ is not well adapted to the institutional structures of forest governance in the DRC, including both statutory and customary tenure. The lack of harmonization between these systems has created a situation of competition between state and customary authorities. This has created opportunities for powerful actors to 'shop' between the two systems to attempt to legitimize their expanded use and control over forest resources. As the REDD+ process evolves from the preparation to the implementation phase, competing institutional structures may negatively impact the effectiveness of REDD+, as well as the distribution of costs and benefits. While the newly enacted community forest law provides an opportunity to recognize customary rights to forestland, the lack of functional local government at the district and village levels has prompted REDD+ pilot project organizers to establish new village organizations for REDD+.
\end{abstract}

Keywords: forest tenure; property rights; authority structures; REDD+; the DRC

\section{Introduction}

The Democratic Republic of Congo (DRC) hosts some of the world's most carbon-rich and biodiverse forests, covering more than $60 \%$ of the national territory with an estimated 17 billion tons of carbon sequestered [1]. The current deforestation rate in the DRC is estimated to be $0.27 \%$ per year [2]. This has motivated the international community to develop several incentive-based policies that aim to increase the provision of public goods from the forest (carbon and biodiversity) by explicitly valuing these goods and incentivizing their protection through different means, including under the umbrella of REDD+ (Reduced Emissions from Deforestation and Forest Degradation). The full expression behind the acronym is 'Reducing Emissions from Deforestation and Forest Degradation, plus the sustainable management of forests, and the conservation and enhancement of forest carbon stocks (REDD+)'. REDD+ is a global climate policy instrument designed to provide financial incentives to tropical forest countries and land owners to reduce carbon emissions from deforestation and forest degradation and protect forest carbon stocks. It is assumed that policies like REDD+ will effectively and efficiently conserve forests as well as improve the livelihoods of forest-dependent communities where poverty tends to be pervasive [3-5]. Whether these goals can be achieved depends greatly on the institutional structures that affect forest practices at the local level.

The implementation of REDD+ requires a clear definition/allocation of property rights as a basis for implementing measures and defining who is entitled to compensation. This is not an easy task in the 
DRC, where the forest is governed by a statutory tenure that co-exists with customary tenure. Colonial and post-colonial policies on forest governance have been based on the substitution of customary tenure systems with statutory tenure systems to pursue the creation of a modern economy based on market principles [6-8]. This transformation has resulted in conflicts between state agents and traditional leaders around who controls (and should control) access to the forests and its resources [9,10]. Although policy debates in recent years have swung back towards recognizing, adapting, and formalizing customary forest tenure, institutional pluralism (in this paper, we used the term 'institutional pluralism' instead of 'legal pluralism' to denote the existence of two or more institutional structures in one social space [11]), including the presence of different authorities, has maintained and contributed to a general fluidity of the institutional framework for forest governance [7,12].

This paper aims to assess the importance of both customary and statutory forest tenures, the adaptations they produce among local actors, and implications of these aspects for the implementation of REDD+ in the DRC. The paper responds to the following questions: (1) How does institutional pluralism affect local forest use? (2) What are the effects of this pluralism on the implementation of REDD+? The empirical data for this study come dominantly from two REDD+ pilot project sites in the Equateur province along from an analysis of policy documents. By doing this, the paper provides empirical evidence to the scholarly literature on REDD+ on the complexity surrounding REDD+ implementation in a fragile state with competing tenure systems. This contribution is relevant for policy action given the fact that tenure security is crucial for effective forest stewardship and REDD+ implementation $[13,14]$.

In the following, Section 2 provides the theoretical framework of the paper by drawing on institutional theories of forest governance. Section 3 presents the geographical context and the research methods. Section 4 presents the nature and dynamics of both customary and statutory tenure of forest governance in the Équateur province. Section 5 analyzes adaptations of local actors operating within the institutional structures described in Section 4. Section 6 discusses the findings in relation to the development of REDD+ projects in the DRC. Section 7 summarizes the main findings and recommends future policy actions.

\section{Conceptualizing Tenure and Property Rights to Forests}

Forest tenure is a social contract, whether defined in customary or statutory terms, that determines who can hold and use the forests for how long and under what conditions [15]. Tenure encompasses property rights, understood as the control over a benefit stream and the ability to call upon the collective to stand behind one's claim to this benefit stream ([16], p. 15). Tenure, therefore, embodies both property rights and the authority structures that enforce and legitimatize claims or control over benefit streams. Customary tenure in this context is typically a set of rules that governs community allocation-access, use, and transfer of forests-as enforced by customary authorities in accordance with the customs and traditions of the community. On the other hand, statutory tenure is a set of rules and regulations enshrined in formalized legislation, decided by a legislature, that determines who can use the forests for how long and under what conditions [17]. While Freudenberger (ibid.) made the distinction that customary tenure depends on unwritten rules, and statutory tenure on written ones, the key point involves differences in authority structure.

Property rights to forests are recognized not as a unitary concept of 'ownership' but as a 'bundle of rights' often involving groups of people with multiple and simultaneous rights and hence, a shared interest in a common resource [18-21]. This bundle of rights may be broken down along a continuum from access, to withdrawal, management, exclusion, and alienation rights [22]. Property rights are also differentiated among a variety of rights holders conceptualized into three categories-states, communities, and individuals [23,24]. The authority that defines the bundle of rights specifying property is crucial to the sense of legitimizing or enforcing these rights in practice. Hence, different strategies for accessing and benefitting from forest resources transcend statutory property rights and may rely on different types of authority [25]. 
In this paper, we use the environmental governance framework developed by Vatn [26] to conceptualize tenure and property rights to forests in the context of institutional pluralism. These structures of forest governance include actors and institutions (Figure 1). Institutions include rules regarding political decision-making-constitutions, gubernatorial decrees, collective choice rules, or customary laws. These decisions create the second type of institution-i.e., those governing the economic process-like property rights. Such rights comprise three elements: user rights, control rights, and alienation rights. User rights are typically access and withdrawal rights, as defined by Schlager and Ostrom [22]. Control rights, also referred to as second-order rights, determine use rights and include management, exclusion, transaction, and monitoring rights [27].

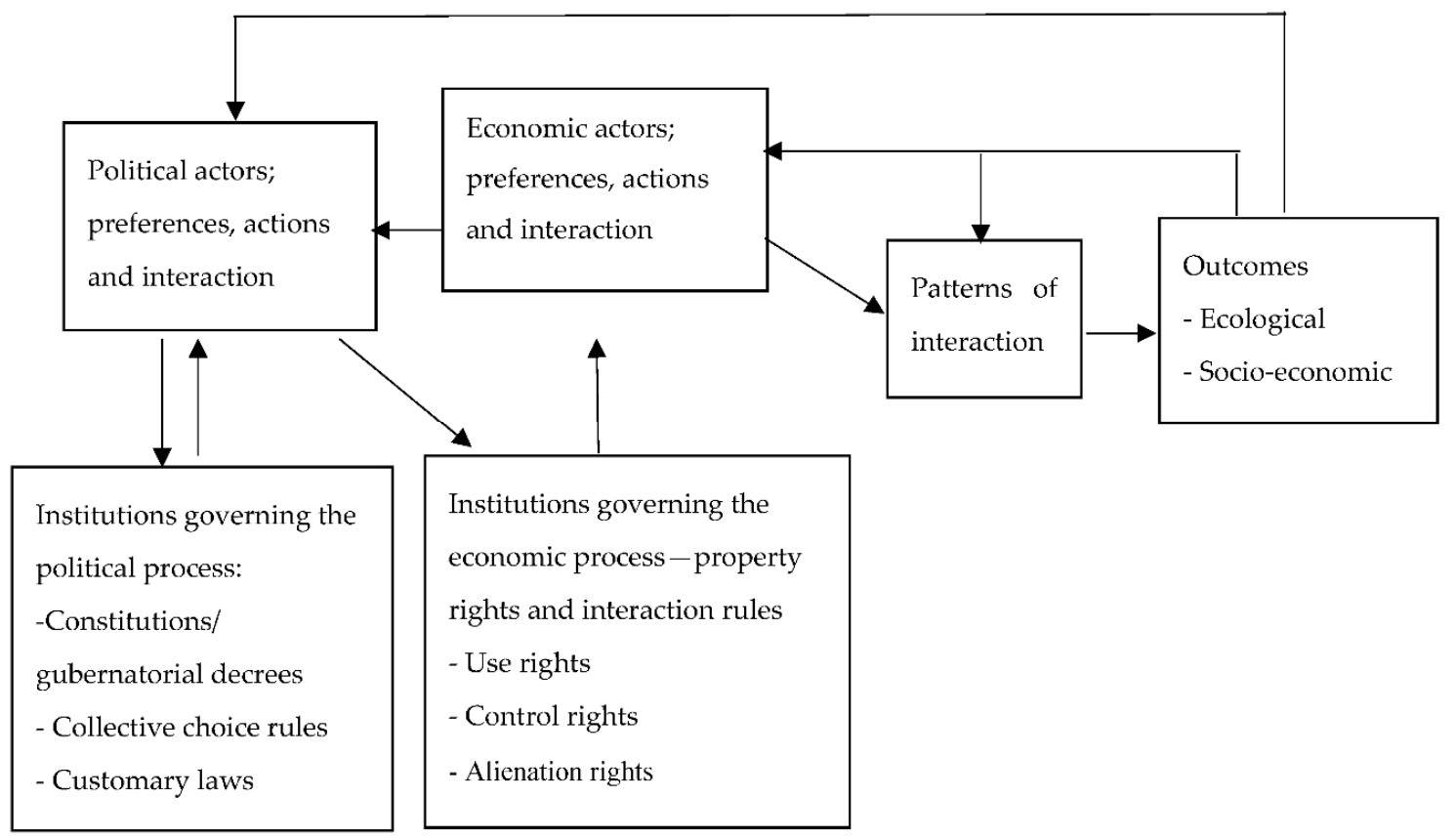

Figure 1. A framework for analyzing forest governance (adapted from [26] 2011, Tapir Academic Press).

Alienation rights are the rights to rent, sell, or transfer rights to others.

Central to our analysis are political and economic actors. Economic actors include local farmers, loggers, and the state as the forest owner that collects revenue through the allocation of timber concessions, but also civil servants when obtaining income from bribes. Political actors include the government, politicians, government agencies involved in forest management, administrators, and traditional authorities who define and enforce the rules of use and the control of forest resources. The political actors are central to our analysis because they have the authority to define and enforce property rights. On the other hand, the economic actors have day-to-day access to the forests and choose which political actors to support and enforce their claims.

In this context, there are two principal types of political actors: state authorities and traditional authorities. The coexistence of the two allows economic actors to choose which authority structure to support their claims. The power of state authorities is enshrined in either the constitution, laws, or gubernatorial decrees, while the power of the traditional authorities is based on customary laws, i.e., rules sanctioned by local customs and traditions that are negotiated and renegotiated over time and space $[7,28]$.

The ways that political actors access their positions are complex in the DRC. State authorities are appointed through elections and political appointments, the latter often based on patron-client relationships [29]. As formal institutions are generally weak, patron-client relationships define who holds political positions. This is true in the forestry sector as well [30,31]. Traditional authorities are appointed through rules based on cultural processes linked to the inheritance of genealogical 
rights [32]. Economic actors may interact with political actors through exchange (the state and logging companies or traditional authorities and local loggers) through command (by state and individuals or communities), by granting formal property rights, or by following local/customary rules [26].

To understand how economic actors deal with these overlapping institutional structures that compete for access to forest resources in Équateur province, we employed the institutional bricolage approach developed by Cleaver [33]. It describes the process by which "people consciously and non-consciously draw on existing social formulae to patch or piece together institutions in response to changing situations" ([34], p. 10). Through this process, actors create space to interpret and re-interpret existing institutions, enabling them to interact, negotiate, and compete with each other to access forest resources $[33,35]$. To create the necessary space to act, actors need to possess certain power resources or mechanisms of access [33]. These power resources are attributes that enable or constrain actors to influence access to forest resources. In forest governance, an economic actor may draw upon different power resources to make claims over forests such as their socio-political position-for example, an official position, formal function, or kinship relations-a social network, economic resources such as wealth, or personal attributes such as knowledge, eloquence, self-confidence, and strength [33].

The environmental governance framework and institutional bricolage framework were selected because they complement each other and provide a better understanding of how institutions and actors operate in practice. While the former focuses on the structural view of power in analyzing institutions, the institutional bricolage approach emphasizes an agent perspective on institutionalized power-how actors operate in relation to institutions.

In the DRC, REDD+ strategies and pilot projects are developed in the context of competing institutional structures for forest governance which are not very different from other Congo Basin countries [36-38]. Consequently, any intervention aimed at promoting sustainable forest management and conservation will have to take into account the existing formal and informal rights over forest resources and the roles of all actors involved. This paper assesses the nature and dynamics of these two conflicting institutional structures of forest governance, how local actors respond to them when legitimatizing use and control rights over forests, and how this might influence the effectiveness of REDD+ on the ground.

\section{Geographical Context and Research Methods}

The data for this paper were collected from two REDD+ pilot sites in the Équateur province of the DRC (Figure 2). The province was divided into five new provinces in July 2015 following the implementation of the decentralization reform of 2006. The data for this analysis were collected following the political and governance structure of the old province before the division. The province has a total area size of $403,292 \mathrm{~km}^{2}$, and hosts 28 per cent of the total forest area in the DRC [39]. The population of the province was estimated to be 3,574,385 inhabitants in 2008, distributed into two main ethnic groups-the Bantu and the Batwa-also known as the Pygmies. The Batwa form only about 20 per cent of the total population and are located in the Southern part of the province. The Bantu is divided into different sub-ethnic groups, such as the Bangala, the Ngwaka in the north of the province; and the Mongo, Ntumba, and Ekonda in the south of the province.

The first pilot site was located in Buya 1 village of Bikoro territory, southwest of the old Equateur province, which is now the new Équateur province. This village has an estimated population of about 3000 inhabitants, with about 300 households located just $42 \mathrm{~km}$ from Mbandaka, the seat of administration for Équateur province. The main ethnic groups are the Mongo and Batwa Pygmies. The Batwa Pygmies living in the village are not considered customary landowners; they are migrants from the Ingende territory. The village is made up of the clans (A clan is a group of families that share actual or perceived kinship and descent. In the Équateur province and other provinces in the DRC, clans are very important traditional forest management groups)—Ekole, Esangele-Nkoy and Djipanga—and migrants from other districts and territories of the province. Its dominant vegetation is 
equatorial swamp rainforest that is inundated year-round, making road construction and maintenance difficult [40].

The second pilot site was located in the Bokumu Mokola village of the Gemena territory, northwest of the old Équateur province, which is now the Sud-Ubangi province. Bokumu-Mokola/Bongo village belongs to the Bominege tribal chiefdom, located about $60 \mathrm{~km}$ from Gemena town. The village has an estimated population of 2700 inhabitants, with about 280 households made up of one ethnic group known as Ngwaka. The pilot site is made up of five clans-Boyabakona, Boyagbandolo, Bobanda, Bogbando, and Boyangadaka. Here, the dominant vegetation is dense, humid, equatorial lowland rainforest that transits into evergreen savannah woodland and grasses in the north. The populations of both pilot sites rely heavily on the forest for their livelihoods via slash and burn shifting cultivation, the extraction of non-timber forest products (NTFPs), fishing, hunting, and the production of charcoal.
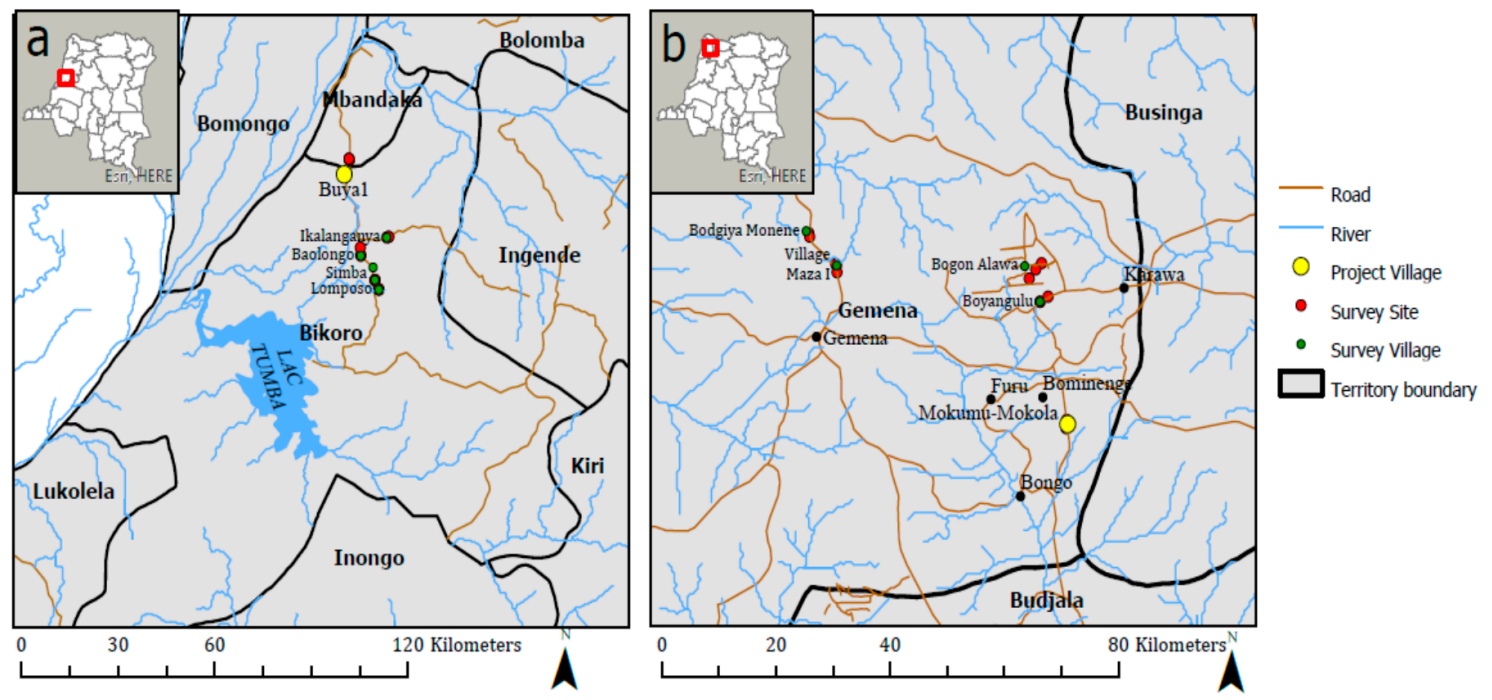

Figure 2. Map of the two pilots in Équateur province: (a) Bikoro territory, Buya 1 project village; (b) Gemena territory, Bokumu-Mokola project village. Source: Chapman (2016).

Table 1 offers an overview of the statutory and customary authority structures. All villages belong to a particular politico-administrative district unit, which, in turn, belongs to a territory and thence, a province. These politico-administrative units are established by statutory law and were reinforced in the 2006 decentralization reform. This reform demanded the establishment of elected local government structures at the different politico-administrative levels. To date, this has occurred only at the provincial level, with the other units still lacking local government structures. Each of these politico-administrative units, from the village to the territory, is thus still governed by a representative with executive power to implement and enforce state laws and resolve local conflicts. On the other hand, people in the study area also belong to traditional jurisdictions known as tribal chiefdoms, known in in French as groupements. These traditional jurisdictions include the villages and clans and are governed by tribal chiefs. The main function of the customary authorities is to exercise control and manage forestland allocation based on customary rules. The relationship between tribal chiefdom as a customary institution and statutory forestland tenure is analyzed in the next section.

The paper combines data from policy documents, interviews, focus group discussions. and field observations from field research conducted in May-July 2013, July-August 2014, and July-August 2015. National and provincial policy documents and administrative texts were examined, and seventy-two in-depth interviews were conducted in French and Lingala with six different types of actors: customary authorities, local administrative authorities, staff of the different intervening agencies, executive members of the village associations, staff of the REDD+ pilot project, and logging operators. The interviewees were selected from the actor and institution mapping list established during the project's baseline study. They were all contacted and interviewed in person at different times based on 
their availability during the field research. The interviews were transcribed and analyzed manually at different stages of the field research process and the corresponding author was the principal researcher who conducted the interviews. Our intention was to gather information on the different institutions that influence forest practices and how actors adapt to these institutions when legitimatizing their rights and access to forests.

Table 1. Characterization of the study area.

\begin{tabular}{|c|c|c|}
\hline Characteristics & Bikoro Pilot Site & Gemena Pilot Site \\
\hline Traditional authorities & $\begin{array}{l}\text { Tribal chief, customary chief, notables, } \\
\text { and customary landowners }\end{array}$ & $\begin{array}{l}\text { Tribal chief, customary chief, notables, } \\
\text { and customary landowners }\end{array}$ \\
\hline Intervening agencies & $\begin{array}{l}\text { World Food Program (WFP), Food and } \\
\text { Agricultural Organization (FAO), Oxfam, } \\
\text { Bureau Diocésain du Développement } \\
\text { (BDD), World Agroforestry Centre (ICRAF) }\end{array}$ & $\begin{array}{c}\text { Humana People to People Congo (HPP), } \\
\text { Communauté Evangélique de l’Ubangi, } \\
\text { Mongala, Gemena (CEUM) }\end{array}$ \\
\hline Forest type & $\begin{array}{l}\text { Dense humid equatorial rainforest } \\
\text { accommodating a large portion of swamp } \\
\text { forests inundated all year round. }\end{array}$ & $\begin{array}{c}\text { Dense humid lowland rainforest } \\
\text { accommodating evergreen savannah } \\
\text { woodland and grasses. }\end{array}$ \\
\hline
\end{tabular}

To capture local actors' insights on how these institutions shape forest practice, and how they respond to them when legitimatizing their practices, we organized nine focus group discussions with ten members in each group. Five groups in the project village in Bikoro (Buya 1), consisting of, respectively, men, women, customary landowners, migrants, and Pygmies, and another four groups in the project village in Gemena (Bokumu Mokola) consisting of men, women, customary landowners, and migrants were convened. The focus groups considered issues related to local people's rights to resources and benefits and their interactions with local authorities when making decisions about forest rights and conflict resolutions. Field observations were collected on the availability and quality of social infrastructures like roads, schools, healthcare and community activities, rights to land, material resources, places for village meetings, and the way local people engage in these meetings.

\section{Forest Tenure Systems at Play in Equateur Province}

Here, we examine the nature and dynamics of customary and statutory tenure systems in the Équateur province.

\subsection{The Nature and Dynamics of Customary Tenure to Forests}

Customary forest tenure is traditionally grouped under a tribal chiefdom (in French: groupement) governed by a tribal chief (in French: chef de groupement). This tribal chief is the highest customary authority in the study area. Each tribal chiefdom is made up of many villages, with the tribal chief being custodian to all forestlands in the chiefdom. The main duties of the tribal chief are to protect the people and the land and to bring fertility to the soil and rivers. Their succession is rotational among the dominant clans of the chiefdoms. Each village that belongs to the tribal chiefdom is governed by a customary village chief. Each village is made up of more than one clan, and the village customary chief is selected from the clan that established the first rights on the village forestland. The customary chief position is based on inheritance among male members of the lineage. Each of the clans are headed by a notable, with acquisition based on inheritance among male members of their lineage. The members of 
the clans are considered customary landowners (in French: ayant droits). These different levels are based on their current geographical location, since some clans now extend to other villages within or beyond the tribal chiefdoms.

The customary system of forest management follows a decentralised model where clans of the village constitute the operational units for production and control of the forest, and customary authorities play a role in the supervision and management of disputes. Each tribal chiefdom has a traditional council headed by the tribal chief with the village customary chiefs as representatives. Similarly, each village has a traditional council headed by a village customary chief with the notables as representatives. The latter makes decisions about village land allocations and enforces property rights over the village forests, while the chiefdom's council makes decisions around land allocation. The legitimacy of the customary authority resides in a cultural belief system transferred from generation to generation. There are also traditional mechanisms of sanctioning these authorities if they misbehave.

Rights holders are classified into three categories: collective (customary authorities), clans (group of families), and individuals. User rights belong to members of clans. This group of right holders claim (exclusive) use rights to all forest resources in the territory of the village. Tradition considers customary landowners to be descendants of the male founder of the clan. He established the territorial rights of first occupation through migration and the establishment of a lineage.

Customary landowners perceive the forests to be a common physical and cultural inheritance from the ancestors. These user rights are passed from generation to generation through the genealogical line of the male descendants of the founder of the clan (see [7]). Non-clan members living in the village may be granted user rights to forest resources upon request. Non-clan and complete outsiders may negotiate access and use rights with the customary chief and notables to harvest high-value forest resources such as poles/sticks, timber, and charcoal. Converting forestland into farmland is a decision made among the clans that make up the village. Each member family of the clans receives land for farming. Non-clan members negotiate use rights to farmland with customary landowners either by renting a parcel of land, sharecropping, or other forms of social exchange.

Control rights belong to the customary chief, notables, and clan members. The village customary chief manages and controls access to the villages' communal land and makes decisions about its allocation. The notables manage and control access to the clans' forestland and allocate land to the family members of the clans for different uses and also resolve internal land conflicts within or between families. Once land has been allocated to the families of a clan, each family establishes productive rights through labor investment. In the Congo Basin, clearing the forest for cultivation and making any labor investment to manage forest resources for productive purposes are the most robust and long-term forms of appropriation associated with exclusive permanent user rights, also known as usufruct rights (see $[7,41]$ ). Families that have control rights to forestland may exclude non-family members from using the land for cultivation. However, clan members can still use resources over which the families have not established permanent use rights, e.g., harvesting firewood, gathering non-timber forest products and medicinal plants, and hunting.

According to customary law, it is forbidden for clan members to sell forestland as it is considered the collective property of the clan. Leasehold, renting, or sharecropping of forestland is allowed. The enforcement of customary rules of access and use are based on local norms. These unwritten rules are overlapping, flexible, and subject to negotiation and renegotiation depending on factors such as the persons involved, the place, even the season.

Today, with the increased presence of state agents and local administrative authorities, the authority of the customary chiefs and notables has weakened. This is especially the case in Bikoro. Information from the interviews and focus groups revealed that the enforcement of customary rules to forestland that are not supported by local government representatives is limited. Many wealthy, well-situated, and knowledgeable-i.e., powerful—village members now use local state agents and authorities to establish access to forestland that was once governed by customary tenure. They prefer to report conflicts over land held under customary tenure to local state authorities, like the district 
chief or a state agency, like the police, rather than reporting them to the customary chiefs and notables. In doing so, they undermine the authority of the customary leaders.

During the men's focus group discussion in Buya1, a village member noted, 'if you report conflicts over land to the customary chief, the solution is based on our culture and the accused is not well sanctioned' (interview, village member in Buya1 village, 2014). Many participants of the focus groups supported this statement. The presence of local state authorities encourages resourceful village members to circumvent customary authorities by establishing social relations with local state authorities (see [42]).

In the Gemena pilot study, customary tenure to forestland was shown to still be strong and the power of customary authorities over forestland was uncontested. This region is characterized by ethnic homogeneity, and local people tend to reject state institutions because they do not relate to their cultural beliefs, norms, and routinized ways of doing things. The presence of state authorities is also limited due to poor roads and few extractive activities.

\subsection{The Nature and Dynamics of Statutory Tenure to Forests}

Statutory forest tenure was established in the 2002 Forest Code, which states that all forests are owned by the state (Art. 7, [43]). Article 10 of the Forest Code classifies the forests in three broad categories: classified forests, protected forests, and permanent production forests. The classified forests are designated for environmental protection and may include nature reserves, forests located in national parks, botanical and zoological gardens, hunting areas, urban forests, etc. In protected forests, user rights are less restricted compared to classified forests. The Forest Code also recognizes customary forest tenure in the protected forests, which was reinforced by the 2006 Constitution. Protected forests may also serve as community forests, since they can be granted to communities upon request. In contrast, permanent production forests are designated for the allocation of logging concessions and forests already used for timber production, identified via a public survey process (Art. 23, [43]).

The 2002 Forest Code recognizes the right of communities with customary claims to the forests to use the forests for their subsistence. It also allows communities with customary rights to extract timber from protected forest through artisanal logging permits (Art. 111-112, [43]). Communities may apply for such permits for a maximum of fifty hectares per year on their own or through a private artisanal logger following an agreement between the community and the logger (Arrete 035, [44]). Individuals of Congolese nationality can apply for artisanal logging permits to harvest timber from the protected forest using long saw or a chainsaw [44,45].

The Forest Code and its administrative texts also grant long-term logging rights (control rights) to concessionaires to exploit timber from production forests. The logging rights to concessionaires are granted for a period of twenty-five years through a bidding process that allows both Congolese and non-Congolese nationals to participate (Art. 83, 85-86, [43]). These logging rights mandate the concessionaires to establish a management plan and to consult communities with customary rights to forests that overlap their concessions to negotiate and sign an agreement for socioeconomic development (Art. 89, [43]). The concessionaire must identify these communities and their legitimate authorities through a legally required socioeconomic survey. An administrative text further provides a model for these agreements by, e.g., defining what should be negotiated between the parties (Arrete 028, [46]). However, this text fails to provide guidelines on how to negotiate the social agreement. Hence, in the past, logging compensations were typically granted on a voluntary basis to the customary authorities while excluding the majority of community members [47]. To ensure equity in benefit sharing, a ministerial text known as Arrêté 023 was adopted in 2010 and provides a new model for the implementation of social agreement (Arrete 023, [48]).

The Forest Code further recognizes community use rights within logging concessions for subsistence but restricts commercial activities and any use deemed incompatible with logging activities (Art. 44, [43]). The Forest Code also allocates control rights to communities through its provision for community forest concessions in protected forests (Art. 22, [43]). The law for the implementation 
of community forests was enacted in August 2014. It advances provisions for communities to have concessions of up to 50,000 ha on a perpetual basis, but the guidelines and procedures for implementation are still under process.

The Forest Code grants the Ministry of Environment, Nature Conservation and Tourism (MECNT) the authority to make decisions on forest allocation and management, to issue logging permits to concessionaires, and to approve any forest management plans and the quantity of timber to be harvested. The Forest Code and its implementing regulations, coupled with the decentralization reform, recognized the authority of provincial governors to issue artisanal logging permits in the provinces upon examination of the application and subsequent recommendations made by the provincial and district forest administration. These authorities are mandated to monitor and enforce all the provisions to the Forest Code and its implementing regulations.

In practice, enforcement of the Forest Code and its implementing regulations is very weak. First, the forest classification is not implemented and there is inconsistency in the Forest Code. Second, forest law enforcement is massively under-resourced in the DRC. Enforcement officers represent just $1 \%$ of the total staff of the MECNT, and most are based in cities, many miles from the logging concessions they are tasked with monitoring. In addition, very few forest officers have any education beyond secondary school, and access to civil service employment is typically based on political patronage $[49,50]$. Third, low salaries, which are paid late or irregularly, weaken the quality of their work. Fourth, bribery and corruption at both the national and local levels is a significant barrier to forest law enforcement [51,52]. Fifth, many local authorities and communities know very little about the details of the Forest Code and especially the new institutional structure created by Arrêté 023. Finally, conflict between the central and provincial authorities regarding the new division of powers in the management of forest royalties and artisanal operations affects forest law enforcement (see also $[12,29,52])$.

\section{Competing Tenures and Forest Practice in Equateur Province}

Here, we describe how the institutional pluralism explained above plays out for two major forest uses-timber extraction and charcoal production-in the study area. We have chosen these two uses as they demonstrate the different ways that local actors adapt to the overlapping institutional structures to legitimatize their forest practices or to make claims on forests.

\subsection{Timber Extraction}

Artisanal logging permits are granted only to Congolese nationals to exploit timber in protected forests specifically, distinct from the categories of general production or classified forests. Since the classification of the forest estate is not enforced or locally formalized, artisanal logging takes place in uncategorized forests, often including forest concession areas, which thus creates confusion and conflict between concessionaires, artisanal operators, and communities. In an interview with the district MECNT administrator of Gemena territory in July 2015, it was revealed that no artisanal logging permits were issued by the governor for 2014-2015. According to him, many of the artisanal loggers in Gemena operated either with authorization letters issued by MECNT officials in Kinshasa or the territorial administrator or without permits.

Information gathered from interviews with five different artisanal loggers operating in the REDD+ pilot site in Gemena revealed that it is difficult to get artisanal logging permits from the governor or MECNT in Kinshasa, as they do not have the needed 'social capital'-e.g., political connection or social network-to do so. Two of the loggers interviewed operated with receipts issued by the district administration of MECNT. These receipts documented that they had paid taxes to the administration to log timber species and, according to them, this is accepted as if it was a logging permit by both customary authorities and local forest officers controlling timber extraction. The other three loggers interviewed operated without permits. They negotiated their logging rights through customary chiefs and the customary landowners and state administration with informal payments. 
These loggers also noted that many artisanal loggers in Gemena operated without permits. They also established social relations with local politicians and military personnel to improve and maintain their negotiation leverage.

Data from interviews and focus group discussions revealed that all artisanal loggers, both with and without permits (tax receipts), had to negotiate their access and use rights to the forest through the customary authority and landowners prior to logging. The negotiation process varied and depended upon the area of forest to be logged and/or the size of the tree's species. The loggers negotiated access rights with the customary authority by providing gifts (alcohol, food, tools, and building materials), including 300-500 USD. If the forest area to be logged had already been allocated to any clan of the village according to customary arrangements, the loggers had to negotiate use rights to the forest with the members of that clan as well by providing payments and gifts. The logger was entitled to the timber species, but the ownership of the forestland remained with the clan (men and customary owners' focus groups at both pilot sites in 2015).

At the Bikoro REDD+ pilot site, three different types of artisanal loggers were identified. One group had logging permits issued by either the governor of the province or top officials at the MECNT in Kinshasa. This group of loggers was considered powerful because they had the material resources, knowledge, and social networks to obtain such logging permits. A group of less well-situated loggers used tax receipts issued from the provincial and district administration of MECNT to establish rights. Those with the weakest relations operated without permits but built social relations with customary authorities and negotiated their way through the administration, either with side payments or by using their social capital, i.e., political loyalty, local networks, and family ties. At the local level (the village), all loggers negotiated their access to the forest with customary authorities and customary landowners. Once the resourceful loggers had negotiated access rights with the customary authorities, they were often reluctant to negotiate their use rights to forests with the customary landowners.

A typical example of this occurred in Penzelle village in 2011-2013, where a powerful artisanal logger operated in the village together with a Chinese partner. The forest area logged was noted as part of a forest concession allocated to a Lebanese logging company (ITB). This artisanal logger operated in the village using heavy machinery without making any agreement with the customary landowners. The local people were unable to influence the logging operation because they were informed that the logger had strong connections both to the governor of the province and the mayor of Mbandaka municipality. The supervisors of the logging operation (two Chinese men) refused to be interviewed by us and asked us to contact the governor of the province or the mayor of Mbandaka municipality.

\subsection{Charcoal Production}

The situation of charcoal production differs strongly from logging. Charcoal production has become a lucrative economic activity in the Équateur province due to increased demand from the principal cities, including Kinshasa. Charcoal production is considered an activity under the use rights of communities. The Forest Code and its administrative texts make provisions for circulation permits for producers and transporters of woody forest products including charcoal. The local forestry department is authorized to issue these permits at the area of extraction and requires inspections at production sites. The local forestry department is also responsible for issuing sale permits to charcoal merchants and collecting tax. The 2006 decentralization reform transferred the authority to issue sale permits for fuelwood and charcoal to the Directorate of New and Renewable Energy at the Ministry of Energy. This Directorate is also responsible for collecting taxes from charcoal sold in the markets.

Data from interviews with local MECNT officials in Mbandaka and Bikoro as well as local administrative authorities revealed that charcoal production is largely regulated by customary institutions and authorities despite the Forest Code provision (MECNT district administrator pers comm.). This provision is little known and seldom applied. Charcoal production takes place in shifting cultivation areas of the forest, fallow land, and in primary forests. The producers are mainly customary landowners living in these villages, although there are some migrants who engage in this activity as 
well. According to these officials and the customary authorities alike, charcoal production is not a primary livelihood activity among local people.

Data from interviews and focus groups in the Bikoro pilot nevertheless indicated that many households are engaged in charcoal production. The presence of the Lebanese logging company in Bikoro provides cheap transportation for charcoal to Kinshasa on the boats that transport its timber. Also, the road that links Bikoro and Mbandaka has reduced transportation costs (including for charcoal) to the town. Bikoro has also witnessed an influx of charcoal merchants in recent years. Many of them pre-finance the production process, provide material support to local producers, and hire labor from the Pygmy population.

The migrants or the merchants who finance the process of charcoal production negotiate use their rights to forest with the customary authorities and customary landowners by either buying trees or renting parcels of forestland to produce charcoal. Many non-clan members living in these villages use forestland to which they have use rights for cultivation to produce charcoal during forest clearing. Information from focus group discussions in the Buya 1 village revealed that many clan members are now restricting non-clan members' rights to produce charcoal on forestland secured for cultivation because of the increasing value of charcoal in the market. Clan members are now demanding non-clan members who want to produce charcoal to negotiate use rights to cut trees standing on forestland secured for cultivation.

At the Gemena pilot site, few customary landowners are involved in charcoal production because of poor roads. The few charcoal merchants operating in the area rent parcels of forestland or buy trees from the customary landowners, including the customary authority, while others pay customary landowners to produce charcoal for them. At the Gemena pilot site, the customary rules prohibit clan members and non-clan members from cutting trees that bear caterpillars for charcoal production. The customary rules are not as strong in Bikoro, since many customary landowners reported the disappearance of trees bearing caterpillars due to logging and charcoal production.

All charcoal merchants are required to have a sale permit, but many operate without them. Many sale taxes are imposed on these merchants by government officials at the markets, at road blocks, and at exit locations. Many transporters and merchants, however, do not pay these taxes but negotiate with government officials at road blocks and exit locations with side payments. Data collected from the interviews and field observations revealed five different government officials that collect taxes from the sale of charcoal. This includes officials from the provincial Ministry of Environment, Ministry of Energy, local territorial and district state authorities, and police department authorities. These different authorities impose different taxes on charcoal transporters and merchants. Similar findings have also been reported in other regions of the DRC $[53,54]$.

In Bikoro, officials of the local MECNT coordination unit collect a sales tax for each bag (about $60 \mathrm{~kg}$ ) of charcoal to be transported to Kinshasa on the boat of a logging company. Many local producers avoid paying this sales tax by selling their products to charcoal merchants that come to villages. Local producers who transport charcoal to the markets in Mbandaka, however, pay tax. Many of them also complained about taxes imposed on them at the market by various local officials.

\section{Institutional Pluralism: What Are the Implications for REDD+?}

The above demonstrates the competing relations between the customary and state authorities in legitimatizing and enforcing forest property rights at the local level, especially around timber extraction. Given such an institutional landscape, actors engaged in forestry invent different ways of dealing with the plurality of power centers at the local level to ensure claims to forest resources-a phenomenon known as forum shopping [18]. Their ability to choose which authority structure to legitimatize their forest use depends, however, on the power resources they possess, i.e., material resources, knowledge, and social relations. In such an institutional landscape, there are no effective checks on the powers of the elite relative to the poor and marginalized; actors with more power resources influence those who govern (see [42]). 
How then can REDD+ be implemented in an institutional landscape with competing authority structures? Power and authority are very important regarding access to resources, as they largely determine who can benefit from resources regardless of whether they have tenure rights or not [55]. Many scholars have pointed out the importance of forest tenure for REDD+ implementation, since REDD+ is set up to reward those who maintain or enhance carbon sequestration in the forest [14,56,57]. As REDD+ is a payment-based mechanism, rights holders to forest carbon should be the ones who are both compensated and held accountable for fulfilling or failing to fulfill their obligations.

Many civil society organizations operating in the DRC believe that REDD+ affords the opportunity to expedite and enhance the tenure security of forest-dependent communities through reform [58,59]. Others claim that REDD+ interventions might increase state control over forestland while risking the exclusion of some categories of forest users [60,61]. More generally, expediting forest tenure reforms might not guarantee effective and legitimate REDD+ implementation if the authority structures that define and enforce rules are weak and if the process involves top-down government imposition of tenure security through land titling as a prerequisite for the participation of local communities. Through such a process, poor communities are likely to be excluded [62].

Based on our findings, implementing REDD+ in a context of institutional pluralism is challenging, since the current situation has different rights holders using different authority structures to legitimatize their claims to resources. Some scholars have proposed the application for a unitary and fixed institutional structure, enforced by state authorities, as a means for delivering REDD+ outcomes [63,64], but this approach might affect the existing bundles of rights to forests, and thus, the sustainability, of REDD+ generally $[65,66]$. Such an approach also might fall short in a context where the state lacks the capacity or resources to define and enforce property rights, as seen in this study. State authorities can lose people's confidence when a lack of accountability prevails, when government officials represent private rather than public interests (as seen above), and when appropriate institutional and enforcement protocols can be evaded or corrupted by bribery.

Although our demonstration of the multiple and overlapping institutional structures described above provides a more accurate understanding of forest practices and thus, a greater flexibility for adapting to changes and uncertainty, the lack of harmonization or coordination between those overlapping institutional structures will likely affect the distribution of REDD+ benefits. Customary rules enforced by customary authorities might deliver reasonable outcomes from REDD+ in traditionally homogeneous communities such as Gemena, but are less likely to succeed in areas where there has been significant in-migration such that founding lineages no longer predominate or have lost some authority (see $[67,68])$.

Customary tenure mirrors the cultural and social values of the community, where the forest is regarded not only as an economic or an environmental asset but also as a social, cultural, and ontological resource that embodies the spirit of the society. The legitimacy of customary authorities largely flows from the community, and their accountability is also based on local norms and customs. In this context, people that share a common background and social history are more likely to trust and respect the customary authorities. Such trust and legitimacy risks decrease if there is perception of corruption and partiality or in situations where customary authorities may not have the knowledge or confidence to deal with pressure from powerful external interests and market penetration. In such circumstances, people may turn to other authority structures (state or international bodies) hoping to get support for their rights claims, even if they fear the loss of autonomy and flexibility that this may entail $[69,70]$. In addition, customary tenure often favors the rights and benefits of the first occupants, i.e., genealogical and differentiated rights between customary landowners and those considered outsiders. This is more visible when forest resources become more coveted and where the rules of use, exchange, and inheritance become more intricate. In the context of REDD+, non-customary landowners and tenants-including vulnerable groups like the Pygmies and women-may be excluded from REDD+ benefits. This is because women and Pygmies do not have decision-making power and 
control over land and forests in the Équateur province [71,72]. This appears to be the case for the distribution of logging compensation in Bikoro territory, as previously documented [42,71].

Since people in our study areas attach considerable trust to customary tenure to secure their rights to forest resources, the formalization of customary tenure in the DRC using the kind of community-based models seen in Tanzania (see [73]) offers a promising opportunity for addressing REDD+ implementation tenure issues in the DRC. Similarly, the DRC's enactment of a community forestry law in August 2014 could further ground attempts to formalize customary rights to forestland [74]. Under this approach, the property rights are perpetually recognized but limited to use and control rights only.

As the modalities and procedures of community forestry in the DRC are under development, early REDD+ pilot projects are applying various mechanisms to recognize customary tenure in their activities [58,59]. They are initiated in the process of introducing REDD+ to these communities using procedures of Free Prior and Informed Consent (FPIC). (FPIC is an important set of principles in the REDD+ social safeguard standard that establishes the rights and conditions for local people's engagement in negotiating the terms of REDD+ interventions that affect their wellbeing and their right to give or withhold their consent to these terms.). While it is typically assumed that local influence on tenure clarification and rights recognition is assured [75], in practice, this process is costly and requires time for proper dissemination of information about REDD+ [57]. In our case study, the REDD+ pilot project organizers conducted the FPIC and started demonstration activities in the communities without yet signing a contractual agreement with the local population. In addition, information about the risks and costs of the project as well as issues related to land rights and forest tenure were not provided or discussed during FPIC. When introducing REDD+, many pilot projects conduct land use planning by engaging the local people through a participatory land use mapping exercise that charts customary use rights. This includes the development of operational rules for resource use and collective choice institutions for management and exclusion.

Because of a lack of harmonization or coordination between the customary and statutory institutional structures of forest governance in the DRC in conjunction with an absence of functional local government at the district and village levels, many REDD+ pilot project organizers-including those in our case study - have facilitated the establishment of a new village organization for REDD+ implementation. This new village organization is called the Local Development Committee, also known in French as Comité Local de Développement (CLD). This new village structure accords with the legal mandate (Law No 08/012 of 31 July 2008 elaborating the decentralization reform in Art 3 of the 2006 constitution) stating that if no local government is in place, a project like REDD+ must establish an CLD. An executive manages this new village organization for REDD+.

While the mechanisms used to create an CLD and executive committee vary among the REDD+ pilot projects, for our case study, household heads sat as members of the CLD and provided the electorate for electing the executive committee. This excluded women from participation, since more than $80 \%$ of the household heads in our case study were men-see also Samndong [76]. In the ERA REDD+ project in Mai-Ndombe, all the members of the village general assembly are considered members of the CLD, and members of the executive committee were elected from the village general assembly [77]. As a mechanism for harmonizing and coordinating this new REDD+ organizational structure with customary institutions in order to build local trust and legitimacy, the president of the CLD in Bikoro is the village customary chief, while the president of the CLD in Gemena is one of the customary landowners. This is also the case for the ERA REDD+ project in Mai-Ndombe, where all of the presidents of the CLD in every village are customary landowners.

While it is still too early to assess the effectiveness of the new village structure for the delivery of REDD+ outcomes, the representativeness and accountability relations of the authority structure in this REDD+ village organization will depend greatly on the social processes and local power dynamics influencing the distribution of REDD+ benefits. This structure is different from the existing structure as it is established through a democratic (if not complete) process, while the existing structure is based 
on local norms and customs. This recognition of the customary chief and customary landowners in allowing them to head the executive committees of these REDD+ organizations might prompt and empower the customary institutions to be more democratically accountable, thus transforming local norms and customs and minimizing the effects of the current pluralist situation. However, if these authorities are not accountable to the local people, it may simply reinforce elite interests and the exclusion of some segments of the population.

While clarifying property rights to forests might be a pre-condition for enabling benefits from REDD+ to occur, the success of these rights is conditional upon the level of ethnic heterogeneity. In the case of the Bikoro pilot site with its high ethnic heterogeneity, such a measure might favor the dominant ethnic group and hence, additional measures could be needed to secure benefits to other ethnic groups. In situations where these rights are weakly enforced, some people might apply different strategies to access and benefit from REDD+ depending on their relationships with the authority structures and their ability to influence decisions.

\section{Conclusions}

This paper documents that the forest in the Equateur province is governed by both statuary and customary tenures. The statuary tenure was introduced by colonial and postcolonial authorities to override customary tenure and enforce state control over forestland and thus, generated a situation of institutional pluralism. While customary tenure is flexible and subject to negotiation, statuary tenure is based on legislation with less flexibility and room for negotiation. The lack of harmonization and coordination between these two tenure systems has created a situation where the state and customary authorities compete to legitimize forest practice at the local level. This has created room for local actors who move across these institutional landscapes to patronize authorities who favor their particular use of forest resources. In this way, empowered local actors (local powerful people-mainly logging operators with permits) can draw on state authorities to support claims to forests or legitimize their use rights, while less empowered local actors instead build relationships with traditional authorities to secure their access and use rights to forests. The situation is exacerbated further by the inconsistency of the statuary tenure and its weak enforcement. As such, local state authorities can reshape statuary tenure provisions before they arrive at the local level as a way of favoring their personal interests. Although such an institutional landscape provides greater flexibility for adapting to changes and uncertainty, any implementation of REDD+ benefits under these institutional conditions will greatly affect their distribution.

For REDD+ to be effective and legitimate at the local level, there is a need to address tenure insecurity and the basis of conflicts over forest access and use. The competing forest tenure systems in the DRC imply that a 'one size fits all' approach to REDD+ is doomed. While recognizing customary tenure seems a better approach for addressing tenure in REDD+ implementation, such an approach first requires land tenure reform. Early actions towards addressing tenure in REDD+ through the establishment of collective choice institutions and land use planning may seem more demanding than a top-down approach, but the former affords a better chance of delivering effective and legitimate REDD+ outcomes at the local level. At the same time, however, the authority structure(s) that undergird collective choice institutions to define and enforce REDD+ rules and benefit distribution locally must also be empowered to be more democratic and accountable in order to avoid elite capture and to ensure legitimate outcomes for REDD+.

Author Contributions: R.A.S.: Conceptualization, developed research instruments, data collection, analyzed data, writing and rewriting. A.V.: project proposal for funding, assist in conceptualization, reviewed and commented in research instruments, assist in writing, editing and rewriting.

Funding: This research was funded by [Norwegian Research Council] grant number [4403040214]. 
Acknowledgments: This research was supported by the Norwegian Research Council through the Man and Forest Research Project 2014-2016. The authors would like to thank all those who participated in the interview survey. We thank two anonymous reviewers for their constructive comments in the early versions of the manuscript. We are grateful to Millie Chapman for producing the maps to our specifications.

Conflicts of Interest: The authors declare no conflict of interest.

\section{References}

1. Laporte, N.; Merry, F.; Baccini, A.; Goetz, S.; Stabach, J.; Bowman, M. Reducing $\mathrm{CO}_{2}$ Emissions from Deforestation and Degradation in the Democratic Republic of Congo: A First Look; Woods Hole Research Center: Falmouth, MA, USA, 2007.

2. GDRC. National REDD+ Framework Strategy of the Democratic Republic of the Congo; Minsitry of Environment Conservation of Nature and Tourism, Ed.; Democratic Republic of Congo UNREDD Programme: Kinshasa, Democratic Republic of the Congo, 2012.

3. Marfo, E.; Acheampong, E.; Opuni-Frimpong, E. Fractured tenure, unaccountable authority, and benefit capture: Constraints to improving community benefits under climate change mitigation schemes in Ghana. Conserv. Soc. 2012, 10, 161-172. [CrossRef]

4. Angelsen, A. Moving ahead with REDD: Issues, Options and Implications; Cifor: Bogor, Indonesia, 2008.

5. Vatn, A.; Vedeld, P.; Petursson, J.; Stenslie, E. The REDD Direction-The Potential for Reduced Forest Carbon Emissions, Biodiversity Protection and Enhanced Development: A Desk Study with Special Focus on Tanzania and Uganda; Norwegian University of Life Sciences Noragric: Ås, Norway, 2009; pp. 1502-8127.

6. Mamdani, M. Preliminary thoughts on the Congo crisis. Soc. Text 1999, 17, 53-62.

7. Diaw, M.C. Modern economic theory and the challenge of embedded tenure institutions: African attempts to reform local forest policies. In Institutions, Sustainability, and Natural Resources; Springer: Berlin, Germany, 2005; pp. 43-81.

8. Unruh, J.D. Carbon sequestration in Africa: The land tenure problem. Glob. Environ. Chang. 2008, 18, 700-707. [CrossRef]

9. Bruce, J.W. Country Profiles of Land Tenure: Africa, 1996; Land Tenure Center, University of Wisconsin-Madison: Madison, WI, USA, 1998; Volume 130.

10. Huggins, C. Land, power and identity. Roots of violent conflict in Eastern DRC. Int. Alert 2010, 1-52.

11. Griffiths, J. What is legal pluralism? J. Leg. Plur. Unoff. Law 1986, 18, 1-55. [CrossRef]

12. Oyono, P.R.; Nzuzi, F.L. Au Sortir d'une Longue «Nuit» Institutionnelle», Perspectives de Gestion Décentralisée des Forêts et des Bénéfices en RD Congo Post-Conflit. Afr. Dév. 2006, 31, 185-216.

13. Cotula, L.; Mayers, J. Tenure in REDD: Start-Point or Afterthought? IIED: London, UK, 2009.

14. Larson, A.M.; Brockhaus, M.; Sunderlin, W.D.; Duchelle, A.; Babon, A.; Dokken, T.; Pham, T.T.; Resosudarmo, I.; Selaya, G.; Awono, A. Land tenure and REDD+: The good, the bad and the ugly. Glob. Environ. Chang. 2013, 23, 678-689. [CrossRef]

15. Sunderlin, W.; Larson, A.M.; Cronkleton, P. Forest tenure rights and REDD+: From inertia to policy solutions. In Realising REDD+: National Strategy and Policy Options; Angelsen, A., Ed.; Center for International Forestry Research: Bogor, Indonesia, 2009; pp. 139-150.

16. Bromley, D.W. Environment and Economy: Property Rights and Public Policy; Basil Blackwell Ltd.: Cambridge, MA, USA; Oxford, UK, 1991.

17. Freudenberger, M.S. The Future of Customary Tenure; USAID: Washington, DC, USA, 2011; p. 18.

18. Meinzen-Dick, R.; Pradhan, R. Legal Pluralism and Dynamic Property Rights. CGIAR Systemwide Program on Collective Action and Property Rights; Working Paper; International Food Policy Research Institute: Washington, DC, USA, 2002.

19. German, L.; Mandondo, A.; Paumgarten, F.; Mwitwa, J. Shifting rights, property and authority in the forest frontier: 'Stakes' for local land users and citizens. J. Peasant Stud. 2014, 41, 51-78. [CrossRef]

20. Galik, C.S.; Jagger, P. Bundles, duties, and rights: A revised framework for analysis of natural resource property rights regimes. Land Econ. 2015, 91, 76-90. [CrossRef]

21. Barry, D.; Larson, A.M.; Colfer, C.J.P. Forest tenure reform: An orphan with many uncles. In Forests for People: Community Rights and Forest Tenure Reform; Larson, A.M., Barry, D., Dahal, G.R., Colfer, C.J.P., Eds.; Earthscan: London, UK, 2010; pp. 19-42. 
22. Schlager, E.; Ostrom, E. Property-rights regimes and natural resources: A conceptual analysis. Land Econ. 1992, 68, 249-262. [CrossRef]

23. Barry, D.; Meinzen-Dick, R. The invisible map: Community tenure rights. In Proceedings of 12th Conference of the International Association for the Study of the Commons, Cheltenham, UK, 14-18 July 2008.

24. Larson, A.M.; Cronkleton, P.; Barry, D.; Pacheco, P. Tenure Rights and Beyond: Community access to Forest Resources in Latin America; Center for International Forestry Research (CIFOR): Bogor, Indonesia, 2008.

25. Sikor, T.; Lund, C. Access and property: A question of power and authority. Dev. Chang. 2009, 40, 1-22. [CrossRef]

26. Vatn, A. Environmental governance-A conceptualization. In The Political Economy of Environment and Development in a Globalised World-Exploring the Frontiers; Vedeld, P., Kjosavik, D.J., Eds.; Tapir Academic Press: Trondheim, Norway, 2011.

27. Sikor, T. Property rights and natural resource governance: Extending the conceptual analysis in times of REDD+. In Proceedings of the International conference on Carbon-Land and Property, Copenhagen, Denmark, 1-4 July 2014.

28. Agbosu, L.K. Land Law in Ghana: Contradiction between Anglo-American and Customary Conceptions of Tenure and Practices; Land Tenure Center, University of Wisconsin-Madison: Madison, WI, USA, 2000.

29. Trefon, T. Congo Masquerade: The Political Culture of Aid Inefficiency and Reform Failure; Zed Books: London, UK, 2011.

30. Trefon, T. Forest Governance in Congo: Corruption Rules; U4 Brief; Chr. Michelsen Institute: Bergen, Norway, 2010.

31. Debroux, L.; Topa, G.; Kaimowitz, D.; Karsenty, A.; Hart, T.; Abdon, A.; Amsini, F.; Aveling, C.; Bertrand, A.; Bekhechi, M. Forests in Post-Conflict Democratic Republic of Congo: Analysis of a Priority Agenda; Sel. Books; Center for International Forestry Research: Bogor Barat, Indonesia, 2007; pp. 1-107.

32. Diaw, M.C. Si, Nda Bot and Ayong: Shifting Cultivation, Land Use and Property Rights in Southern Cameroon; ODI: London, UK, 1997.

33. Cleaver, F. Reinventing institutions: Bricolage and the social embeddedness of natural resource management. Eur. J. Dev. Res. 2002, 14, 11-30. [CrossRef]

34. Cleaver, F. Development through Bricolage: Rethinking Institutions for Natural Resource Management; Routledge: Abingdon-on-Thames, UK, 2012.

35. de Koning, J. Reshaping Institutions-Bricolage Processes in Smallholder Forestry in the Amazon. Unpublished Ph.D. Thesis, Wageningen University, Wageningen, The Netherlands, 2011.

36. Ingram, V.; Ros-Tonen, M.A.; Dietz, A.J. A fine mess: Bricolaged forest governance in Cameroon. Int. J. Commons 2015, 9, 24. [CrossRef]

37. Assembe-Mvondo, S.J.A.S. Local communities' and indigenous peoples' rights to forests in Central Africa: From hope to challenges. Afr. Spectr. 2013, 48, 25-47.

38. Laird, S.A.; Ingram, V.; Awono, A.; Ndoye, O.; Sunderland, T.; Fotabong, E.L.; Nkuinkeu, R. Integrating customary and statutory systems: The struggle to develop a legal and policy framework for NTFPs in Cameroon. In Wild Product Governance: Finding Policies that Work for Non-Timber Forest Products; Earthscan: London, UK, 2010; pp. 53-70.

39. UNDP. Plan Quinquennal de Developpement de la Province de l'Equateur (2010-2014); UNDP Office: Mbandaka, Democratic Republic of the Congo, 2009.

40. Yamba, P.K. Congo Basin-DRC: Case Studyon the Ngiri-Tumba-Maindombe Wetland Landscape; Institute for Environmental Security: The Hague, The Netherlands, 2009.

41. Graziani, M.; Burnham, P.; Homewood, K. Legal pluralism in the rain forests of South-eastern Cameroon. In Rural Resources and Local Livelihoods in Africa; Palgrave Macmillan: New York, NY, USA, 2005; pp. 177-197.

42. Samndong, R.A. Institutional Choice and Fragmented Citizenship in Forestry and Development Interventions in Bikoro Territory of the Democratic Republic of Congo. Forum Dev. Stud. 2015, 2, 251-279. [CrossRef]

43. GDRC. Forest Code. Law No. 11/2002. 29 August 2002.

44. MECNT. Arrêté 035 and Arrêté 105, the Ministerial Orders that lay out procedures for the granting of various logging permits. Arrêté n ${ }^{\circ}$ 35/CAB/MIN/ ECN-EF/2006 du. 05 Octobre 2006.

45. Global-Witness. The Art of Logging Industrially in the Congo: How Loggers are Abusing Artisanal Permits to Exploit the Democratic Republic of Congo's Forests; 0957322828; Global Witness: London, UK, 2012.

46. MECNT. Arrête Ministériel No. 028/CAB/MIN/ECN-T/15/JEB/09 of August 20. 2008. 
47. Seyler, J.R.; Thomas, D.; Mwanza, N.; Mpoyi, A. Democratic Republic of Congo: Biodiversity and Tropical Forestry Assessment (118/119); USAID/Democratic Republic of the Congo: Washington, DC, USA, 2010.

48. MECNT. Arrête No. 023/CAB/MIN/ECN-T/JEB10 10 du 07 Juin 2010.

49. Lawson, S. Illegal Logging in the Democratic Republic of the Congo; Chatham House: London, UK, 2014.

50. Samndong, R.A.; Nhantumbo, I. Natural Resources Governance in the Democratic Republic of Congo: Breaking Sector Walls for Sustainable Land Use Investments; IIED: London, UK, 2015.

51. Kodi, M. Corruption and Governance in the DRC during the Transition Period (2003-2006); No. 148; Institute for Security Studies Monographs: Dakar, Senegal, 2008; 114p.

52. Benneker, C. Forest Governance in DRC: Artisanal Logging, Moving Forward with Forest Governance; Tropenbos: Wageningen, The Nertherland, 2012; pp. 29-35.

53. Trefon, T.; Hendriks, T.; Kabuyaya, N.; Ngoy, B. L'économie Politique de la Filière du Charbon de bois à Kinshasa et à Lubumbashi; University of Antwerp: Antwerp, Belgium, 2010.

54. Schure, J.; Ingram, V.; Arts, B.; Levang, P.; Mvula-Mampasi, E. Institutions and access to woodfuel commerce in the Democratic Republic of Congo. For. Policy Econ. 2015, 50, 53-61. [CrossRef]

55. Ribot, J.C.; Peluso, N.L. A theory of access. Rural Sociol. 2003, 68, 153-181. [CrossRef]

56. Resosudarmo, I.A.P.; Atmadja, S.; Ekaputri, A.D.; Intarini, D.Y.; Indriatmoko, Y.; Astri, P. Does tenure security lead to REDD+ project effectiveness? Reflections from five emerging sites in Indonesia. World Dev. 2014, 55, 68-83. [CrossRef]

57. Sunderlin, W.D.; Larson, A.M.; Duchelle, A.E.; Resosudarmo, I.A.P.; Huynh, T.B.; Awono, A.; Dokken, T. How are REDD+ proponents addressing tenure problems? Evidence from Brazil, Cameroon, Tanzania, Indonesia, and Vietnam. World Dev. 2014, 55, 37-52. [CrossRef]

58. Aquino, A.; Guay, B. Implementing REDD+ in the Democratic Republic of Congo: An analysis of the emerging national REDD+ governance structure. For. Policy Econ. 2013, 36, 71-79. [CrossRef]

59. Mpoyi, A.M.; Nyamwoga, F.B.; Kabamba, F.M.; Assembe-Mvondo, S. The Context of REDD+ in the Democratic Republic of Congo: Drivers, Agents and Institutions; CIFOR: Bogor, Indonesia, 2013; Volume 94.

60. Fobissie, K.; Alemagi, D.; Minang, P.A. REDD+ Policy Approaches in the Congo Basin: A Comparative Analysis of Cameroon and the Democratic Republic of Congo (DRC). Forests 2014, 5, 2400-2424. [CrossRef]

61. Phelps, J.; Webb, E.L.; Agrawal, A. Does REDD+ threaten to recentralize forest governance? Science 2010, 328, 312-313. [CrossRef] [PubMed]

62. Corbera, E.; Estrada, M.; May, P.; Navarro, G.; Pacheco, P. Rights to land, forests and carbon in REDD+: Insights from Mexico, Brazil and Costa Rica. Forests 2011, 2, 301-342. [CrossRef]

63. Karsenty, A.; Vogel, A.; Castell, F. "Carbon rights", REDD+ and payments for environmental services. Environ. Sci. Policy 2014, 35, 20-29. [CrossRef]

64. Karsenty, A.; Assembé, S. Land tenure and implementation of REDD+ in Central Africa. Land Tenure J. 2011, 2.

65. Loft, L.; Ravikumar, A.; Gebara, M.F.; Pham, T.T.; Resosudarmo, I.A.P.; Assembe, S.; Tovar, J.G.; Mwangi, E.; Andersson, K. Taking stock of carbon rights in REDD+ candidate countries: Concept meets reality. Forests 2015, 6, 1031-1060. [CrossRef]

66. Jagger, P. Confusion vs. clarity: Property rights and forest use in Uganda. For. Policy Econ. 2014, 45, 32-41. [CrossRef]

67. Fitzpatrick, D. 'Best practice' options for the legal recognition of customary tenure. Dev. Chang. 2005, 36, 449-475. [CrossRef]

68. Meinzen-Dick, R.; Mwangi, E. Cutting the web of interests: Pitfalls of formalizing property rights. Land Use Policy 2009, 26, 36-43. [CrossRef]

69. Larson, A.; Marfo, E.; Cronkleton, P.; Pulhin, J. Authority relations under new forest tenure arrangements. In Forests for People: Community Rights and Forest Tenure Reform; Earthscan: London, UK, 2010.

70. Marfo, E.; Colfer, C.; Kante, B.; Elías, S. From discourse to policy: The practical interface of statutory and customary land and forest rights. In Forests for People: Community Rights and Forest Tenure Reform; Larson, A.M., Ed.; Earthscan: London, UK, 2010; pp. 69-92.

71. Samndong, R.A.; Kjosavik, D. Gendered forests: Exploring gender dimensions in forest governance and REDD+ in Équateur Province, Democratic Republic of Congo (DRC). Ecol. Soc. 2017, 22, 34. [CrossRef] 
72. Stiem, L.; Krause, T. Exploring the impact of social norms and perceptions on women's participation in customary forest and land governance in the Democratic Republic of Congo-Implications for REDD+. Int. For. Rev. 2016, 18, 110-122. [CrossRef]

73. Dokken, T.; Caplow, S.; Angelsen, A.; Sunderlin, W.D. Tenure issues in REDD+ pilot project sites in Tanzania. Forests 2014, 5, 234-255. [CrossRef]

74. Maindo, A.; Kapa, F. La Foresterie Communautaire en RDC: Premières Expériences, Défis et Opportunités; Tropenbos International: Wageningen, The Netherlands, 2014; p. 159.

75. Fobissie, K. Experiences and Lessons Learned on REDD+ Social and Governance Safeguards in Cameroon; COMIFAC: Yaounde, Cameroon, 2014; p. 39.

76. Samndong, R.A. Socio-Economic Baseline Study of REDD+ Pilot Project in Equateur Province; Unpublished Field Report; Wood Hole Resarch Centre: Mbandaka, Democratic Republic of the Congo, Unpublished work; 2014.

77. Nhantumbo, I.; Samndong, R.A. Inclusive REDD+: Private sector engagement in REDD+ of the Democratic Republic of Congo (DRC), The case of ERA/WWC Mai Ndombe REDD+ project. In Field Report; International Institute for Environment and Development (IIED): London, UK, 2016.

(C) 2018 by the authors. Licensee MDPI, Basel, Switzerland. This article is an open access article distributed under the terms and conditions of the Creative Commons Attribution (CC BY) license (http://creativecommons.org/licenses/by/4.0/). 